\title{
Monitoring and assessment of heavy metal contamination in surface water and sediment of the Old Brahmaputra River, Bangladesh
}

\author{
Md. Simul Bhuyan ${ }^{1} \cdot$ Muhammad Abu Bakar ${ }^{2} \cdot$ Md. Rashed-Un-Nabi $^{1} \cdot$ Venkatramanan Senapathi $^{3,4}$ (1) \\ Sang Yong Chung ${ }^{5} \cdot$ Md. Shafiqul Islam ${ }^{1}$
}

Received: 31 August 2017 / Accepted: 13 June 2019 / Published online: 21 June 2019

(c) The Author(s) 2019

\begin{abstract}
The present study was conducted to measure globally alarming of ten heavy metals ( $\mathrm{Pb}, \mathrm{Cd}, \mathrm{Cr}, \mathrm{Cu}, \mathrm{Hg}, \mathrm{Al}, \mathrm{Ni}, \mathrm{Co}, \mathrm{Zn}$ and $\mathrm{Mn}$ ) in surface water and sediment of the Old Brahmaputra River in Bangladesh. The observed order of heavy metal mean concentration in water and sediments is $\mathrm{Al}>\mathrm{Mn}>\mathrm{Ni}>\mathrm{Co}>\mathrm{Cu}>\mathrm{Pb}>\mathrm{Zn}>\mathrm{Cr}>\mathrm{Cd}>\mathrm{Hg}$ in $\mathrm{mg} / \mathrm{l}$ and $\mathrm{Al}>\mathrm{Mn}>\mathrm{Zn}>\mathrm{Ni}>$ $\mathrm{Pb}>\mathrm{Cr}>\mathrm{Cu}>\mathrm{Co}>\mathrm{Cd}>\mathrm{Hg}$ in $\mathrm{mg} / \mathrm{kg}$, respectively. The significant variations of $\mathrm{Cr}, \mathrm{Cu}, \mathrm{Al}$ and $\mathrm{Ni}$ were found in the water of all seasons $(p<0.05)$, while sediment showed $\mathrm{Pb}$ and $\mathrm{Hg}$ exhibited substantial changes in terms of seasons $(p<0.05)$. Principal component analysis and correlation matrix revealed that significant anthropogenic input of $\mathrm{Pb}, \mathrm{Cd}, \mathrm{Cr}, \mathrm{Cu}, \mathrm{Hg}, \mathrm{Al}$, $\mathrm{Ni}, \mathrm{Co}, \mathrm{Zn}$ and $\mathrm{Mn}$ in water and sediment. In case of water, very strong linear relationships exhibited in $\mathrm{Ni}$ versus $\mathrm{Cu}(0.911)$, $\mathrm{Ni}$ versus $\mathrm{Al}$ (0.910), $\mathrm{Mn}$ versus $\mathrm{Co}$ (0.882), $\mathrm{Cr}$ versus $\mathrm{Al}$ (0.877), $\mathrm{Cu}$ versus $\mathrm{Cd}(0.853)$, $\mathrm{Ni}$ versus $\mathrm{Pb}(0.850), \mathrm{Zn}$ versus $\mathrm{Cr}$ (0.833), $\mathrm{Ni}$ versus $\mathrm{Cd}(0.828)$, $\mathrm{Cu}$ versus $\mathrm{Cr}(0.827)$, $\mathrm{Al}$ versus $\mathrm{Cd}(0.827)$ and $\mathrm{Zn}$ versus $\mathrm{Co}(0.804)$ at the significance level 0.05 . In sediments, very strong linear relationships were noted in $\mathrm{Zn}$ versus $\mathrm{Cr}(0.889)$, $\mathrm{Al}$ versus $\mathrm{Pb}(0.848)$, Co versus $\mathrm{Al}$ (0.819) and Mn versus Co (0.806) at the significance level 0.05 . The result discovered that water and sediment quality of the Old Brahmaputra River became contaminated due to the anthropogenic sources of industrial, domestic and irrigation discharges. This environmental monitoring and assessment research will be useful for the management and planning for the protection of this river.
\end{abstract}

Keywords Heavy metals $\cdot$ Contamination $\cdot$ Water $\cdot$ Sediment $\cdot$ Statistical analysis $\cdot$ Old Brahmaputra River

\section{Introduction}

Contamination of heavy metals in river water and sediments is the major environmental focus especially during the last decade (Ozmen et al. 2004; Fernandes et al. 2008)

Venkatramanan Senapathi

venkatramanan@tdtu.edu.vn

1 Faculty of Marine Sciences and Fisheries, University of Chittagong, Chittagong, Bangladesh

2 Bangladesh Council of Scientific and Industrial Research, Chittagong, Bangladesh

3 Department for Management of Science and Technology Development, Ton Duc Thang University, Ho Chi Minh City, Vietnam

4 Faculty of Applied Sciences, Ton Duc Thang University, Ho Chi Minh City, Vietnam

5 Department of Earth Environmental Sciences, Pukyong National University, Busan, South Korea because of their profusion, persistence and toxicity (Islam et al. 2015a; Ahmed et al. 2015a, b). Heavy metal contamination of river water and surface sediments becomes the major quality problems in fast developing cities since water and sediment quality maintenance and hygiene structure do not grow along with population and urbanization (Ahmad et al. 2010). Both natural and anthropogenic activities are largely liable for the heavy metal abundance in the environment (Wilson and Pyatt 2007; Khan et al. 2008). Massive deposit of toxic heavy metals is discharged by anthropogenic activities (Gao et al. 2009; Nduka and Orisakwe 2011) as well as by natural process that also contributes to the metal contamination in aquatic environment (Tarra-Wahlberg et al. 2001; Jordao et al. 2002; Khan et al. 2008; Bai et al. 2011; Grigoratos et al. 2014; Martin et al. 2015). Geological weathering, industrial disposal of metals and metal components, leaching of metals from garbage, solid waste heaps, animal and human excreta are major sources of heavy metals (Forstner 1983). Moreover, metal contamination in aquatic 
ecosystems is due to the effects of unplanned urbanization and haphazard industrialization (Zhang et al. 2011; Bai et al. 2011; Grigoratos et al. 2014; Martin et al. 2015; Bhuyan and Islam 2017, Chung et al. 2018). These activities can generate heavy metals in sediment and water that pollute the aquatic environment (Sanchez-Chardi et al. 2007).

In an aquatic ecosystem, heavy metals scavenged by fine particles lead to their accumulation in sediments. The contamination of heavy metals in water and sediments has produced significant adverse ecologic effects (Yi et al. 2011; Islam et al. 2014; Martin et al. 2015; Islam et al. 2015b, c; Ahmed et al. 2015c). However, the level of the risks is very tough to measure accurately, due to the difficulty of biologic and chemical interactions that is hugely responsible for the alteration of the bioavailability of metals. It may undergo regular changes due to dissolution, precipitation and absorption which affect their performance and bioavailability (Nicolau et al. 2006; Nouri et al. 2011). Heavy metals are released from sediments by the processes of re-suspension of particulates and activities of micro-organisms within the sediments and at the sediment-water interface. These soluble forms of the heavy metals may be found in crustaceans, finfish and shellfish (NNPC and RIP 1986) and can be shifted to humans via the food chain pathways (Camusso et al. 1995; Sun et al. 2001; Zhou et al. 2004; Sharma et al. 2007; Yi et al. 2011; Alhashemi et al. 2012; Pan and Wang 2012; Rahman et al. 2013; Islam et al. 2015a; Ahmed et al. 2015a, b).

Sediments have been extensively regarded as environmental pointers for the evaluation of metal pollution in the watercourse (Islam et al. 2015d). Among the environmental pollutants, metals are of specific concern because of their possible toxic effects and capability to bioaccumulate in aquatic ecosystems (Censi et al. 2006). Sediment is an important part of the river basin, with the deviation of habitats and environments (Morillo et al. 2004). Thus, it is necessary to evaluate the concentrations of heavy metals in water and sediments.

Today, metal pollution has become the major problem in many fast-growing emerging countries like Bangladesh (Islam et al. 2015c; Kibria et al. 2016a, b; Bhuyan et al. 2016; Bhuyan and Islam 2017). The discharge of municipal wastes, unprocessed effluents from various industries and agricultural inputs in the open water bodies and rivers has created a frightening situation in Bangladesh (Venugopal et al. 2009; Islam et al. 2015a, c).

In Bangladesh, the Old Brahmaputra River is one of the most important rivers. Being the part of industrial developed zone, the pollution is increasing day by day, especially heavy metal pollution. This river is receiving a huge amount of untreated effluents from various industries such as textile crafts, dying industries, spinning mills, cotton, jute mills and others. High concentration of various heavy metals such as
$\mathrm{Al}, \mathrm{Mn}, \mathrm{Ni}, \mathrm{Pb}$ and $\mathrm{Cu}$ is discharged into the Old Brahmaputra River which contributes largely to pollution of the surface water and sediments. Unfortunately, no scientific research regarding heavy metal pollution in surface water and sediment of the Old Brahmaputra River has been conducted so far. Therefore, the foremost objectives of the present study were to determine the heavy metal concentrations in water and sediment. It is expected that this research can contribute to the identification of heavy metal contamination sources and origin and to the effective conservation and management of Old Brahmaputra River system.

\section{Materials and methods}

\section{Sampling sites}

The Old Brahmaputra River, close to the Narsingdi district $\left(24^{\circ} 08^{\prime} 03.76^{\prime \prime} \mathrm{N} \& 90^{\circ} 47^{\prime} 09.62^{\prime \prime} \mathrm{E}\right)$, is one of the most important ecosystems with more aquaculture farms (Fig. 1). It plays a very important role in minimizing rural poverty and supplying food to the poor fishing community as well as for local people. It is an active river that plays a significant role in morphological changes in the downstream area (Amacher et al. 1989). Continuous variations of the river's course constitute a significant factor in the hydrology of the Brahmaputra. Samples were collected at Drenerghat $\left(24^{\circ} 08^{\prime} 54.42^{\prime \prime} \mathrm{N}\right.$ $\left.\& 90^{\circ} 42^{\prime} 02.64^{\prime \prime} \mathrm{E}\right)$ and Belanagor $\left(23^{\circ} 56^{\prime} 19.12^{\prime \prime} \mathrm{N}\right.$ and $\left.90^{\circ} 42^{\prime} 36.07^{\prime \prime} \mathrm{E}\right)$ (Fig. 1). There are lot of textile craft industries and dying industries along the Old Brahmaputra River. Moreover, domestic sewage adds another pollution dimension of the river. In summer season, the river water layer gets down and water gets mixed with the pollutants discharged by these industries.

\section{Geological information}

The Brahmaputra River is a trans-boundary river which flows through China, India and Bangladesh. In Bangladesh, the Brahmaputra is linked by the Teesta River (one of its largest tributaries). The Brahmaputra River gets split into two distributary branches below the Teesta. The western branch contains the majority of the river's flow which continues as the Jamuna to merge with the lower Ganga, named the Padma River. The eastern branch is called the lower or Old Brahmaputra River. Brahmaputra River starts its $3000 \mathrm{~km}$ journey to the Bay of Bengal from the slopes of Kailash in western Tibet. The Tsangpo known as Tibet's great river crosses from east to the high-altitude Tibetan plateau, north of the Great Himalayan Range with various myriad channels and sandbanks on its way. It comes down from Sadiya in the south of Arunachal Pradesh and passes through the Dibrugarh, Neamati, Tezpur, Guwahati and 


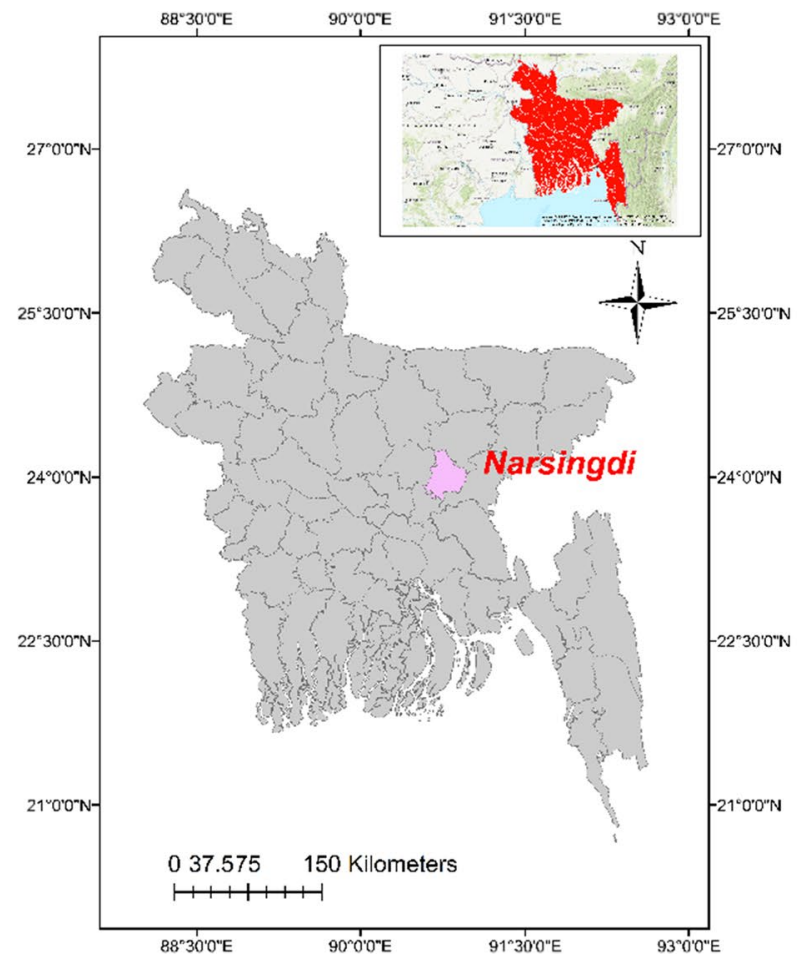

Fig. 1 Map showing sampling points of the Old Brahmaputra River

finally joins the Padma, the easternmost branch of the Ganges. This connected watercourse then flows into Bangladesh where it joins with the Meghna River. The Brahmaputra is navigable for favourable geological properties, especially for its length. The lower part of this river is revered to Hindus. Being one of the major rivers that are prone to tides in the world, the river is exposed to catastrophic flooding in spring when the Himalayan snows start to melt. Late Quaternary sediments of the Brahmaputra basin revealed a history of river swapping and climate change as exposed from sandand clay-size mineralogy of shafts and up-to-date riverbed grabs. Epidote-to-crimson ratios in sand fraction sediments are diagnostic of the source with high $\mathrm{E} / \mathrm{G}$ that designates Brahmaputra origin and low E/G indicates Ganges prominence. The Brahmaputra contains kaolinite (29\%), illite (63\%) and chlorite (3\%) (Bhuyan and Islam, 2017).

The Ganges and Brahmaputra rivers have changed their position several times during the Holocene that is indicated by the analysis of mineralogical and stratigraphic data of Brahmaputra basin. Prolonged eras of mixed river inputs seem to be distant to the Early Holocene, representing rapid migrating and meandering channels during sea level low stand. During much of the Holocene, tectonic elevation of Sylhet Basin may have contributed to the larger course of this river. Varying degrees of physical and chemical weathering indicate the abundances of illite and chlorite contrast to smectite and kaolinite. In early post-glacial deposits, a

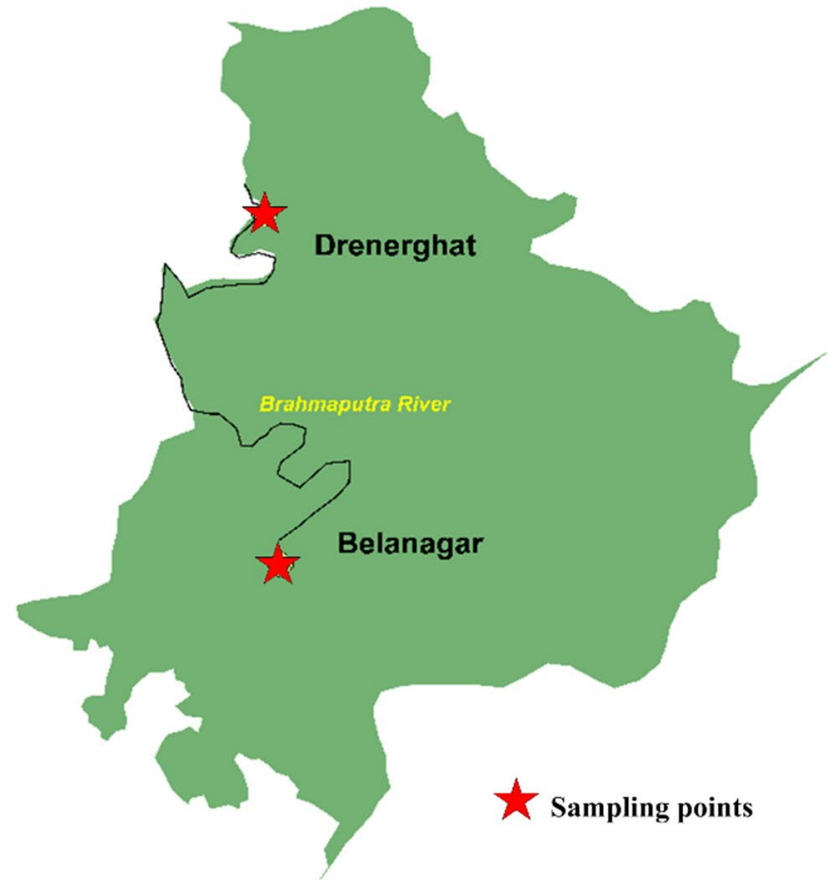

dominance of physical weathering was suggested by High IC values in the Brahmaputra river course. Several geological changes in the basin were reported by improved chemical weathering under increasingly warmer and more humid conditions (Bhuyan et al. 2016).

\section{Sample collection and preservation}

A total of 12 surface water sample and 12 surface sediment samples were collected at three phases: September 2015 (rainy season), January 2016 (winter season) and March 2016 (pre-monsoon). Two litres of surface water sample was collected. Immediately after collection, water sample was acidified with nitric acid $(\mathrm{pH}=2)$ and was transferred to the laboratory.

\section{Heavy metal determination}

The heavy metal contents of collected water and sediments were determined by atomic absorption spectroscopy (AAS, model iCE 3300, Thermo Scientific, UK) using standard analytical procedure (Table 1). Samples were carefully handled to avoid contamination. Glassware was properly cleaned by chromic acid and distilled water. Analyticalgrade chemicals and reagents were used for blank determination and instrument readings. The techniques for sample 
Table 1 Spectral lines used in emission measurements and the instrumental detection limit for the elements measured by using ICP-AES

\begin{tabular}{lll}
\hline Elements & Wavelength $(\mathrm{nm})$ & $\begin{array}{l}\text { Instrumental } \\
\text { detection limit } \\
(\mathrm{mg} / \mathrm{l})\end{array}$ \\
\hline $\mathrm{Hg}$ & \\
$\mathrm{Pd}$ & 253.7 & 0.013 \\
$\mathrm{Cr}$ & 217.0 & 0.0054 \\
$\mathrm{Co}$ & 357.9 & 0.01 \\
$\mathrm{Cd}$ & 240.7 & 0.0028 \\
$\mathrm{Mn}$ & 228.8 & 0.0016 \\
$\mathrm{Ni}$ & 279.5 & 0.008 \\
$\mathrm{Zn}$ & 232.0 & 0.0033 \\
$\mathrm{Cu}$ & 213.9 & 0.0045 \\
$\mathrm{Al}$ & 324.8 & 0.028 \\
\hline
\end{tabular}

and standard preparation and analysis of metal have been briefly described below.

\section{Sample preparation (sediment)}

This procedure was also used for the destruction of organic matter. Precaution was to be taken to avoid losses by volatilization of elements. The samples were weighed accurately, and a suitable quantity (10 to $20 \mathrm{~g}$ ) was transferred to a silica crucible. After that, the samples were dried at $120^{\circ} \mathrm{C}$ in a laboratory oven. These dishes were then placed in the muffle furnace at ambient temperature, and the temperature is raised slowly to $450{ }^{\circ} \mathrm{C}$ at a rate of no more than $50{ }^{\circ} \mathrm{C} / \mathrm{h}$. The samples were ignited in a muffle furnace at $450{ }^{\circ} \mathrm{C}$ for at least $8 \mathrm{~h}$. After the samples are cooled, the dishes were removed from furnace. Then the sediment samples were digested in desired amount of 50\% nitric acid on hot plate. Again samples were filtrated into a 100-ml volumetric flask using Whatman No. 44 filter paper and the residue was washed. Each sample solution was made up to the mark with distilled water (Chung et al. 2018).

\section{Sample preparation (water)}

A $100 \mathrm{ml}$ water of each of the water samples was taken in a beaker. Then the samples were digested by adding $5 \mathrm{ml}$ conc. $\mathrm{HNO}_{3}$ on a hot plate. After that, the samples were filtrated into a $100-\mathrm{ml}$ volumetric flask using Whatman No. 44 filter paper and made up to the mark with distilled water.

\section{Standard preparation}

All samples were prepared from chemicals of analytical grade with distilled water. $1 \mathrm{gm}$ of metal cadmium, copper, lead and nickel was dissolved in $\mathrm{HNO}_{3}$ solution; $1 \mathrm{~g}$ of cobalt, iron, manganese, zinc and aluminium was dissolved in $\mathrm{HCl}$ solution; $2.8289 \mathrm{~g} \mathrm{~K}_{2} \mathrm{Cr}_{2} \mathrm{O}_{7}$ (=1 g chromium) was dissolved in water and made up to $1 \mathrm{~L}$ in volumetric flask with distilled water; thus, stock solution of $1000 \mathrm{mg} / \mathrm{l}$ of $\mathrm{Cd}, \mathrm{Cu}, \mathrm{Pb}, \mathrm{Ni}, \mathrm{Co}, \mathrm{Fe}, \mathrm{Mn}, \mathrm{Zn}, \mathrm{Al}$ and $\mathrm{Cr}$ was prepared. Then $100 \mathrm{ml}$ of $0.1,0.25,0.5,0.75,1.0$ and $2.0 \mathrm{mg} / \mathrm{l}$ of working standards of each metal except iron was prepared from the stock using micropipettes in $5 \mathrm{ml}$ of $2 \mathrm{~N}$ nitric acid. $100 \mathrm{ml}$ of $2.0,2.5,5.0,10.0$ and $20.0 \mathrm{mg} / \mathrm{l}$ of working standards of iron metal was prepared from iron stock solution. Reagent blank was prepared in the same manner of sample preparation without sample to avoid reagent contamination (Thompson and Howarth 1976; APHA 1995).

\section{Analysis of sample}

The atomic absorption instrument was set up, and flame condition and absorbance were optimized. Then blanks (deionized water), standards, sample blank and samples were aspirated into the flame in AAS (model iCE 3300). The calibration curves were obtained for concentration versus absorbance. Data were statistically analysed using fitting of straight line by least square method. A blank reading was also taken, and necessary corrections were made during the calculation of concentration of various elements.

\section{Statistical analysis}

The research data sets were interpreted with various statistical analyses using SPSS (version 22). The one-way analysis of variance (ANOVA) was performed by the concentration of heavy metals in terms of seasons and sites. G-Graph was used for the graphical appearance of heavy metal in seasons and sites. Principal component analysis (PCA) was carried out on the source of heavy metal contamination. Pearson's product-moment correlation matrix was obtained to identify the relationship between the metals. Cluster analysis (CA) is an effective tool to find out the similarity and variation with the influencing factors on different data sets (Wang et al. 2014). Moreover, CA is an important tool for the characterization and simplification of data sets with the behaviour they possess. CA (dendrogram) was performed to show the similarity among variables and to identify their sources of origin using PRIMER (version 6). 


\section{Results and discussion}

\section{Seasonal variation of heavy metal levels in surface water samples}

The concentration of heavy metals in surface water and its comparison with other rivers of Bangladesh are given in Table 2. The mean concentration of heavy metals is shown in Fig. 2 and Table 3. The observed concentration of heavy metals is in the following order: $\mathrm{Al}>\mathrm{Mn}>\mathrm{Ni}>$ $\mathrm{Co}>\mathrm{Cu}>\mathrm{Pb}>\mathrm{Zn} \mathrm{Cr}>\mathrm{Cd}>\mathrm{Hg}$ in $\mathrm{mg} / \mathrm{l}$. The concentrations of $\mathrm{Al}$ ranged between 1.5 and $11.5 \mathrm{mg} / \mathrm{l}$. A higher concentration $(11.5 \mathrm{mg} / \mathrm{l})$ of $\mathrm{Al}$ was recorded at Belanagor in post-monsoon. The concentration exceeded the admissible limit $(0.2 \mathrm{mg} / \mathrm{l})$ set by ECR (1997). The lowest concentration of $\mathrm{Al}(1.15 \mathrm{mg} / \mathrm{l})$ in monsoon season is at Belanagor. The highest concentration of $\mathrm{Mn}$ was recorded $(2.5 \mathrm{mg} / \mathrm{l})$ at Belanagor during post-monsoon that was above the permissible limit of standards as WHO (2004), ECR (1997) and EPA (1986). This concentration is also above the value recorded. This is due to the geogenic origin and also attributed to the minor input of anthropogenic sources (Balkis et al. 2010; Mokaddes et al. 2013). Ni concentration in water varied from 0.02 to $0.8 \mathrm{mg} / \mathrm{l}$. A higher concentration of Ni was noted $(0.8 \mathrm{mg} / \mathrm{l})$ at Drenerghat in

Table 2 Comparison of the observed values of heavy metals in the water of the Old Brahmaputra River with other rivers of Bangladesh

\begin{tabular}{llllllllllll}
\hline River & $\mathrm{Pb}$ & $\mathrm{Cd}$ & $\mathrm{Cr}$ & $\mathrm{Cu}$ & $\mathrm{Hg}$ & $\mathrm{Al}$ & $\mathrm{Ni}$ & $\mathrm{Co}$ & $\mathrm{Zn}$ & $\mathrm{Mn}$ & $\mathrm{References}$ \\
\hline Old Brahmaputra River & 0.11 & 0.001 & 0.01 & 0.12 & 0.001 & 6.87 & 0.44 & 0.2 & 0.01 & 1.44 & Present study \\
Buriganga & 0.07 & 0.009 & 0.59 & 0.163 & - & - & 0.008 & - & - & - & Ahmad et al. (2010) \\
Buriganga & 0.112 & 0.059 & 0.114 & & & & 0.15 & & 0.332 & 0.157 & Bhuiyan et al. (2015) \\
Balu & 0.001 & 0.008 & - & 0.01 & - & - & - & - & 0.02 & 0.03 & Mokaddes et al. (2013) \\
Dhaleshwari & 0.05 & 0.006 & 0.44 & 0.15 & - & - & 0.007 & - & - & - & Ahmed et al. (2009) \\
Dhaleshwari & 0.20 & 0.00 & 0.13 & 0.00 & - & - & - & - & - & - & Ahmed et al. (2012) \\
Khiru & 0.02 & 0.13 & - & 0.004 & - & - & - & - & 0.006 & 0.17 & Rashid et al. (2012) \\
Karatoa & Trace & - & 0.005 & Trace & - & - & 0.005 & - & Trace & 0.101 & Zakir et al. (2012) \\
Karnofuly & 0.14 & 0.01 & 0.25 & 0.05 & - & - & - & - & 0.28 & 0.12 & Islam et al. (2013) \\
Meghna & $\mathrm{BDL}$ & 0.003 & 0.035 & & - & - & $\mathrm{BDL}$ & - & 0.036 & 0.009 & Hassan et al. (2015) \\
Shitalakhya & 0.001 & 0.01 & - & 0.005 & - & - & - & - & 0.02 & 0.05 & Mokaddes et al. (2013) \\
Shitalakhya & 0.05 & 0.003 & 0.08 & 0.04 & & & 0.02 & & 0.72 & Islam et al. (2014) \\
Turag & 0.002 & 0.01 & - & 0.004 & - & - & - & - & 0.02 & 0.06 & Mokaddes et al. (2013) \\
\hline
\end{tabular}

Fig. 2 Graph showing mean concentrations $(\mathrm{mg} / \mathrm{l})$ of heavy metals in water during three seasons

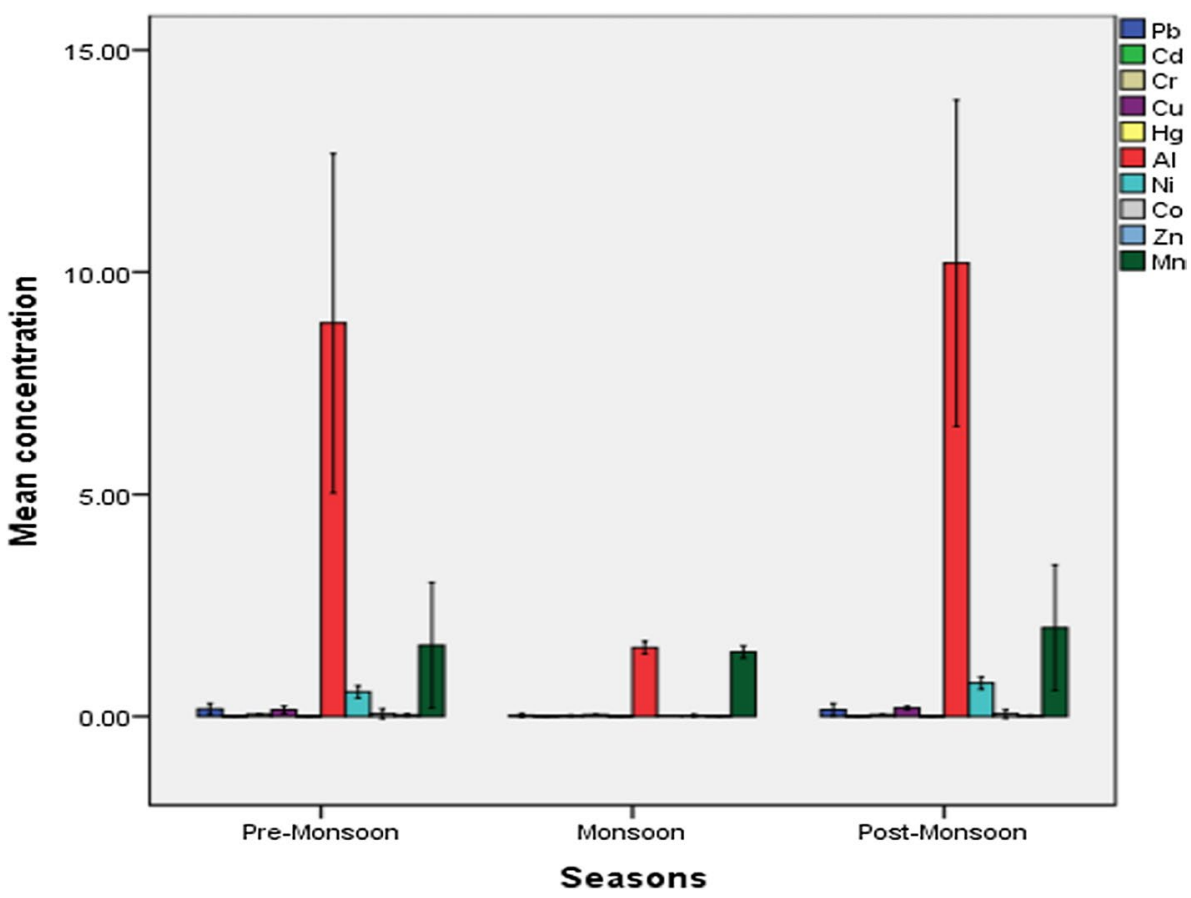

Seasons 
Table 3 Concentration of heavy metals in water and sediment at different sites in different seasons

\begin{tabular}{llllllllllll}
\hline Sites & Seasons & $\mathrm{Pb}$ & $\mathrm{Cd}$ & $\mathrm{Cr}$ & $\mathrm{Cu}$ & $\mathrm{Hg}$ & $\mathrm{Al}$ & $\mathrm{Ni}$ & $\mathrm{Co}$ & $\mathrm{Zn}$ & $\mathrm{Mn}$ \\
\hline Heavy metals in water $(m g / l)$ & & & & & & & & & & \\
Belanagor & Pre-monsoon & 0.12 & $\mathrm{BDL}$ & $\mathrm{BDL}$ & 0.18 & $\mathrm{BDL}$ & 10.2 & 0.5 & $\mathrm{BDL}$ & $\mathrm{BDL}$ & 2.1 \\
Drenerghat & & 0.21 & $\mathrm{BDL}$ & $\mathrm{BDL}$ & 0.12 & $\mathrm{BDL}$ & 7.5 & 0.6 & $\mathrm{BDL}$ & $\mathrm{BDL}$ & 1.1 \\
Belanagor & Monsoon & $\mathrm{BDL}$ & $\mathrm{BDL}$ & $\mathrm{BDL}$ & 0.04 & $\mathrm{BDL}$ & 1.5 & 0.02 & $\mathrm{BDL}$ & $\mathrm{BDL}$ & $\mathrm{BDL}$ \\
Drenerghat & & 0.04 & $\mathrm{BDL}$ & $\mathrm{BDL}$ & 0.03 & $\mathrm{BDL}$ & 1.6 & 0.02 & 0.03 & $\mathrm{BDL}$ & 1.4 \\
Belanagor & Post-monsoon & 0.10 & $\mathrm{BDL}$ & $\mathrm{BDL}$ & 0.2 & $\mathrm{BDL}$ & 11.5 & 0.7 & $\mathrm{BDL}$ & $\mathrm{BDL}$ & 2.5 \\
Drenerghat & & 0.20 & $\mathrm{BDL}$ & $\mathrm{BDL}$ & 0.17 & $\mathrm{BDL}$ & 8.9 & 0.8 & $\mathrm{BDL}$ & $\mathrm{BDL}$ & 1.5 \\
Heavy metals in sediment $(\mathrm{mg} / \mathrm{kg})$ & & & & & & & & & \\
Belanagor & Pre-monsoon & 8.8 & $\mathrm{BDL}$ & 6.4 & 6.2 & $\mathrm{BDL}$ & 10,000 & 12.9 & 4.6 & 51.2 & 145 \\
Drenerghat & & 8.1 & $\mathrm{BDL}$ & 5.2 & 5.7 & $\mathrm{BDL}$ & 8800 & 11.3 & 3.7 & 33.5 & 101 \\
Belanagor & Monsoon & 4.8 & $\mathrm{BDL}$ & 7.5 & 6.8 & $\mathrm{BDL}$ & 8200 & 11.5 & 3.85 & 81 & 105 \\
Drenerghat & & 5.6 & $\mathrm{BDL}$ & 8 & 6.2 & $\mathrm{BDL}$ & 6900 & 13.5 & 3.9 & 65 & 145 \\
Belanagor & Post-monsoon & 9.8 & $\mathrm{BDL}$ & 6.5 & 6.4 & $\mathrm{BDL}$ & 11,200 & 14 & 4.8 & 52.5 & 155 \\
Drenerghat & & 8.5 & $\mathrm{BDL}$ & 5.8 & 5.8 & $\mathrm{BDL}$ & 8900 & 13.5 & 3.9 & 32.78 & 106 \\
\hline
\end{tabular}

a post-monsoon season that exceeded the allowable limit set by WHO (2004) and ECR (1997). A minimum concentration of $\mathrm{Ni}$ was observed $(0.02 \mathrm{mg} / \mathrm{l})$ at Belanagor and Drenerghat in monsoon season. The emission of contamination was caused by textile and dying industries (Ahmad et al. 2010; Faisal et al. 2004). Average Co concentration $(0.20 \mathrm{mg} / \mathrm{l})$ was measured at Drenerghat. Co is favourable to health, but the excess level of Co may pose lung and heart effects and dermatitis (ATSDR 2004). This is probably represented by geogenic and industrial inputs. A higher concentration of $\mathrm{Cu}$ was noted $(0.2 \mathrm{mg} / \mathrm{l})$ at Belanagor station in post-monsoon, and the average concentration of $\mathrm{Cu}$ is $0.12 \mathrm{mg} / \mathrm{l}$, which is far below the allowable limit set of standards set by WHO (2004), EPA (2002) and ECR (1997). The concentration of $\mathrm{Pb}$ was recorded between 0.01 and $0.21 \mathrm{mg} / \mathrm{l}$. The highest concentration was $0.21 \mathrm{mg} / \mathrm{l}$ at Drenerghat in pre-monsoon season. $\mathrm{Pb}$ exhibited the permissible limit set by standards of WHO (2004), USEPA (2006), EPA (2002) and ECR (1997). Moreover, Hassan et al. (2015) found the Pb concentration below detection limit from the Meghna River, Bangladesh. The lowest concentration $0.01 \mathrm{mg} / \mathrm{l}$ was recorded at Belanagor in monsoon season. $\mathrm{Zn}$ was found between BDL and $0.01 \mathrm{mg} / \mathrm{l}$. This is significantly affected by paint and textile industries and associated with the discharge of sewage and irrigation runoff (Ahmad et al. 2010; Mokaddes et al. 2013). The concentration of $\mathrm{Cr}$ was observed between BDL and $0.01 \mathrm{mg} / \mathrm{l}$, which was found below the limits of WHO (2004), USEPA (2006), ECR (1997). The concentration of $\mathrm{Cd}$ ranged from $\mathrm{BDL}$ to $0.001 \mathrm{mg} / \mathrm{l}$. The maximum amount of $\mathrm{Cd}$ was recorded $(0.001 \mathrm{mg} / \mathrm{l})$ above the tolerable limits of USEPA 2006 and ECR (1997). In the case of $\mathrm{Hg}$, it varied between BDL and $0.001 \mathrm{mg} / \mathrm{l}$. This concentration was found within the limits of WHO (2004), ECR (1997), USEPA (2006). This is because of the effluents from industries and urban wastes (Ahmad et al. 2010).

\section{ANOVA findings}

ANOVA provided significant variations in the concentrations of $\mathrm{Cr}, \mathrm{Cu}, \mathrm{Al}$ and $\mathrm{Ni}$ that were found in terms of seasons $(p<0.05)$. No significant variations $(p>0.05)$ exhibited in metals $\mathrm{Pb}, \mathrm{Cd}, \mathrm{Hg}, \mathrm{Co}, \mathrm{Zn}$ and $\mathrm{Mn}$. Moreover, predominant variations $(p>0.05)$ in the metal concentrations were recorded in terms of sites $(p>0.05)$.

\section{Correlation matrix}

Correlation matrix showed that a very strong linear relationship was found in $\mathrm{Ni}$ versus $\mathrm{Cu}$ (0.911), Ni versus $\mathrm{Al}$ (0.910), Mn versus Co (0.882), Cr versus Al (0.877), Cu versus $\mathrm{Cd}$ (0.853), Ni versus $\mathrm{Pb}(0.850), \mathrm{Zn}$ versus $\mathrm{Cr}$ (0.833), $\mathrm{Ni}$ versus $\mathrm{Cd}$ (0.828), $\mathrm{Cu}$ versus $\mathrm{Cr}$ (0.827), Al versus $\mathrm{Cd}$ (0.827) and $\mathrm{Zn}$ versus $\mathrm{Co}(0.804)$ at the significance level of 0.05 (Table 4). Moreover, Al versus $\mathrm{Cu}(0.992)$ and $\mathrm{Zn}$ versus Hg (0.949) showed very strong linear relationship at the significance level 0.01. A strong relationship was observed in $\mathrm{Cr}$ versus $\mathrm{Cd}$ (0.760), $\mathrm{Hg}$ versus $\mathrm{Cr}$ (0.754), $\mathrm{Cd}$ versus $\mathrm{Pb}$ (0.742), Co versus $\mathrm{Cr}(0.742)$ and $\mathrm{Ni}$ versus $\mathrm{Cr}(0.719)$ at the level of 0.01 . These results indicated that there was some original relationship between heavy metals, and revealed two different probable heavy metal sources such as anthropogenic and lithogenic (Islam et al. 2016a, b).

\section{Seasonal variation of heavy metal levels in surface sediment samples}

The concentration of heavy metals in surface sediments and its comparison with other rivers of Bangladesh are given 
Table 4 Correlation matrix of heavy metals in water

\begin{tabular}{lllllllllll}
\hline & $\mathrm{Pb}$ & $\mathrm{Cd}$ & $\mathrm{Cr}$ & $\mathrm{Cu}$ & $\mathrm{Hg}$ & $\mathrm{Al}$ & $\mathrm{Ni}$ & $\mathrm{Co}$ & $\mathrm{Zn}$ & $\mathrm{Mn}$ \\
\hline $\mathrm{Pb}$ & 1 & & & & & & & & \\
$\mathrm{Cd}$ & 0.742 & 1 & & & & & & & \\
$\mathrm{Cr}$ & 0.629 & 0.760 & 1 & & & & & & \\
$\mathrm{Cu}$ & 0.620 & 0.853 & 0.827 & 1 & & & & & & \\
$\mathrm{Hg}$ & 0.296 & 0.635 & 0.754 & 0.460 & 1 & & & & & \\
$\mathrm{Al}$ & 0.646 & 0.827 & 0.877 & 0.992 & 0.484 & 1 & & & & \\
$\mathrm{Ni}$ & 0.850 & 0.828 & 0.719 & 0.911 & 0.253 & 0.910 & 1 & & & \\
$\mathrm{Co}$ & -0.006 & 0.454 & 0.742 & 0.678 & 0.618 & 0.695 & 0.343 & 1 & & \\
$\mathrm{Zn}$ & 0.217 & 0.574 & 0.833 & 0.567 & 0.949 & 0.603 & 0.302 & 0.804 & 1 & \\
$\mathrm{Mn}$ & -0.194 & 0.304 & 0.453 & 0.641 & 0.259 & 0.619 & 0.312 & 0.882 & 0.492 & 1 \\
\hline
\end{tabular}

Table 5 Comparison of the observed values of heavy metals in the surface sediment of the Old Brahmaputra River with other rivers of Bangladesh

\begin{tabular}{llllllllllll}
\hline River & $\mathrm{Pb}$ & $\mathrm{Cd}$ & $\mathrm{Cr}$ & $\mathrm{Cu}$ & $\mathrm{Hg}$ & $\mathrm{Al}$ & $\mathrm{Ni}$ & $\mathrm{Co}$ & $\mathrm{Zn}$ & $\mathrm{Mn}$ & References \\
\hline Old Brahmaputra River & 7.6 & 0.48 & 6.6 & 6.2 & 0.001 & 9000 & 12.8 & 4.1 & 52.7 & 126.2 & Present study \\
Buriganga & 69.75 & 3.33 & 177.5 & 27.85 & - & - & 200.5 & - & - & - & Ahmad et al. (2010) \\
Buriganga & 79.8 & 0.8 & 101.2 & 184.4 & - & - & - & - & 502.3 & - & Saha and Hossain (2011) \\
Buriganga & 31.4 & 1.5 & 173.4 & 344.2 & - & - & 153.3 & - & 481.8 & 4036 & Mohiuddin et al. (2015) \\
Bangshi & 59.99 & 0.61 & 98.1 & & & & 25.67 & & 117.15 & 483.4 & Rahman et al. (2014) \\
Dhaleshwari & 15.79 & 2.08 & 27.39 & 37.45 & - & - & - & - & - & - & Ahmed et al. (2012) \\
Khiru & 5.60 & 2.05 & - & 34.7 & - & - & - & - & 97.77 & 28.56 & Rashid et al. (2012) \\
Karnofuly & 4.96 & 0.24 & 0.76 & 1.22 & - & - & - & - & 16.30 & 15.30 & Islam et al. (2013) \\
Karatoa & 58 & 1.20 & 109 & - & - & - & 95 & - & - & - & Islam et al. (2015c) \\
Meghna & 9.47 & 0.23 & 31.74 & - & - & - & 76.1 & - & 79.02 & 442.6 & Hassan et al. (2015) \\
Shitalakhya & 28.36 & 5.01 & 63.22 & - & - & - & 39.22 & - & 75 & - & Islam et al. (2014) \\
Shitalakhya & - & - & 74.82 & 143.7 & - & $30,432.4$ & - & 13.37 & 200.6 & - & Islam et al. (2016a, b) \\
Turag & 1.64 & 1.4 & 0.44 & 1.576 & - & - & - & - & 1.08 & - & Banu et al. (2013) \\
\hline
\end{tabular}

in Table 5. The mean concentration of heavy metals was observed in the following order: $\mathrm{Al}>\mathrm{Mn}>\mathrm{Zn}>\mathrm{Ni}>\mathrm{Pb}>$ $\mathrm{Cr}>\mathrm{Cu}>\mathrm{Co}>\mathrm{Cd}>\mathrm{Hg} \mathrm{mg} / \mathrm{kg}$ (Fig. 3). Al concentration in sediments is ranged from 6900 to $11,200 \mathrm{mg} / \mathrm{kg}$. The higher concentration of $\mathrm{Al}(11,200 \mathrm{mg} / \mathrm{kg})$ was recorded at Belanagor in post-monsoon. The lowest quantity of $\mathrm{Al}(6900 \mathrm{mg} /$ $\mathrm{kg}$ ) was found at Drenerghat in monsoon season. Al concentration of sediments was above the permissible limit of FAO (1985).

The concentration of Mn was noted between 101 and $155 \mathrm{mg} / \mathrm{kg}$. The highest level of Mn (155 mg/kg) was recorded at Belanagor, while the lowest concentration of $\mathrm{Mn}$ $(101 \mathrm{mg} / \mathrm{kg})$ was established at Drenerghat in pre-monsoon. The concentrations exceeded the permissible limit set by WHO (2008), USEPA (1999) and FAO (1985). It is suggested that the concentration $\mathrm{Al}$ and $\mathrm{Mn}$ originated from the lithogenic and is also associated with spinning miles and paint industries wastes (Rahman et al. 2014; Hassan et al. 2015). The concentration of $\mathrm{Zn}$ varied from 32.78 to $81 \mathrm{mg} /$ $\mathrm{kg}$. A higher concentration of $\mathrm{Zn}(81 \mathrm{mg} / \mathrm{kg})$ was recorded at Belanagor, and lower concentration of $\mathrm{Zn}(32.78 \mathrm{mg} / \mathrm{kg})$ was noted at Drenerghat in monsoon and post-monsoon seasons, respectively. This is above the limits of WHO (2008) and FAO (1985). Ni concentration was ranged from 11.3 to $14 \mathrm{mg} / \mathrm{kg}$. A higher concentration of $\mathrm{Ni}(14 \mathrm{mg} / \mathrm{kg})$ was observed at Belanagor in post-monsoon, while the lower level of $\mathrm{Ni}(11.3 \mathrm{mg} / \mathrm{kg})$ was noted at Drenerghat in premonsoon. Ni was found below the allowable limits of WHO (2004) and USEPA (1999) but higher than the limits of FAO (1985). The concentration of $\mathrm{Pb}$ ranged between 4.8 and $9.8 \mathrm{mg} / \mathrm{kg}$. The highest concentration of $\mathrm{Pb}(9.8 \mathrm{mg} /$ $\mathrm{kg}$ ) recorded at Belanagor in post-monsoon. This result is above the limit of FAO (1985). Effluents are from textile and paint industries and domestic waste runoff from the urban environment (Saha and Hossain 2011; Banu et al. 2013). The concentration of $\mathrm{Cr}$ varied between 5.2 and $7.5 \mathrm{mg} /$ $\mathrm{kg}$, whereas the higher concentration $(7.5 \mathrm{mg} / \mathrm{kg}$ ) of $\mathrm{Cr}$ was observed at Belanagor in monsoon season. The concentration of Cr was below the allowable limits of WHO (2004) and USEPA (1999). The concentration of $\mathrm{Cu}$ varied from 
5.7 to $6.8 \mathrm{mg} / \mathrm{kg}$. The maximum level of $\mathrm{Cu}(6.8 \mathrm{mg} / \mathrm{kg})$ was noted at Belanagor in monsoon season. These results exceeded the permissible limits of FAO (1985). The concentrations of Co found ranged from 3.7 to $4.8 \mathrm{mg} / \mathrm{kg}$. The highest concentration of Co $(4.8 \mathrm{mg} / \mathrm{kg})$ was recorded at Belanagor in post-monsoon. It is indicates that the concentrations exceeded the admissible limits $(0.05 \mathrm{mg} / \mathrm{kg})$ of WHO (2008) and FAO (1985). The concentrations of Cd were ranged between BDL and $0.54 \mathrm{mg} / \mathrm{kg}$. The results are below the permissible limits of WHO (2004) and USEPA (1999). $\mathrm{Hg}$ concentration was recorded below the detection limit in all sediment samples in all seasons. A higher concentration of these metals was affected by discharges of textile and paint industries and domestic sewage waste (Datta and Subramanian 1998; Balkis et al. 2010; Ergul et al. 2008; Ahmad et al. 2010; Saha and Hossain 2011; Ahmed et al. 2012; Hassan et al. 2015).

\section{ANOVA findings}

Substantial changes in the concentrations of $\mathrm{Pb}$ and $\mathrm{Hg}$ were found in sediment in terms of seasons $(p<0.05)$. However, there are no significant variations $(p>0.05)$ in $\mathrm{Cr}, \mathrm{Cu}, \mathrm{Al}$, $\mathrm{Ni}, \mathrm{Cd}, \mathrm{Co}, \mathrm{Zn}$ and $\mathrm{Mn}$. In the case of sites, no significant variations were found in the metal concentrations $(p>0.05)$.

\section{Correlation matrix}

Strong linear relationships were found in $\mathrm{Zn}$ versus $\mathrm{Cr}$ (0.889), $\mathrm{Al}$ versus $\mathrm{Pb}(0.848)$, Co versus $\mathrm{Al}(0.819)$ and $\mathrm{Mn}$ versus $\mathrm{Co}(0.806)$ at the significance level 0.05 . $\mathrm{Zn}$ versus $\mathrm{Cu}$ (0.925) showed very strong linear relationship at the significance level 0.01. Strong relationships were observed in $\mathrm{Cd}$ versus $\mathrm{Pb}(0.788), \mathrm{Cu}$ versus $\mathrm{Cr}(0.735)$ and $\mathrm{Mn}$ versus $\mathrm{Ni}(0.726)$ at the significance level of 0.05 . In the case of grain size and metals, good linear relationships were observed in $\mathrm{Ni}$ versus \% sand (0.953), $\mathrm{Cu}$ versus organic matter (0.925) and $\mathrm{Cu}$ versus organic carbon (0.924) at the significance level 0.01 , and $\mathrm{Zn}$ versus $\%$ organic carbon $(0.721), \mathrm{Zn}$ versus \% organic matter $(0.737), \mathrm{Hg}$ versus $\%$ sand $(0.708)$ at the significance level of 0.05 . Moderate relationships were observed in Mn versus \% sand (0.598), $\mathrm{Pb}$ versus \% sand (0.561) and Co versus \% organic carbon (0.506) at the significance level 0.05 (Table 6). It suggested that grain size and organic matter and carbon play an important role in scavenging heavy metals in sediments (Venkatramanan et al. 2015a, b).
Table 6 Correlation matrix of heavy metals in sediment

\begin{tabular}{rrrrc} 
\%Silt & \%Sand & \%Clay & $\begin{array}{l}\text { \%Organic } \\
\text { carbon }\end{array}$ & \%Organic matter \\
\hline-0.515 & 0.561 & -0.592 & -0.143 & -0.236 \\
-0.265 & 0.331 & -0.509 & -0.345 & -0.376 \\
0.030 & -0.019 & -0.035 & 0.447 & 0.426 \\
0.345 & -0.264 & -0.144 & 0.924 & 0.925 \\
-0.666 & 0.708 & -0.681 & -0.112 & -0.128 \\
-0.229 & 0.327 & -0.635 & 0.391 & 0.310 \\
-0.910 & 0.953 & -0.859 & -0.016 & -0.141 \\
-0.380 & 0.488 & -0.795 & 0.506 & 0.371 \\
0.401 & -0.364 & 0.109 & 0.721 & 0.737 \\
-0.551 & 0.598 & -0.620 & 0.297 & 0.136
\end{tabular}

Table 7 Component matrix of two-factor model with strong to moderate loadings in water

\begin{tabular}{lcr}
\hline Water & & \\
\hline Eigenvalues (0.5) & Component & \multicolumn{1}{c}{ PC 2 } \\
\cline { 2 - 3 } & PC 1 & 0.020 \\
$\mathrm{~Pb}$ & 1.000 & 0.364 \\
$\mathrm{Cd}$ & 0.932 & 0.091 \\
$\mathrm{Cr}$ & 0.996 & -0.263 \\
$\mathrm{Cu}$ & 0.965 & 0.742 \\
$\mathrm{Hg}$ & 0.670 & -0.268 \\
$\mathrm{Al}$ & 0.963 & -0.427 \\
$\mathrm{Ni}$ & 0.904 & -0.050 \\
$\mathrm{Co}$ & 0.999 & 0.533 \\
$\mathrm{Zn}$ & 0.846 & -0.531 \\
Mn & 0.847 & 1.584 \\
Eigenvalue & 8.416 & 15.843 \\
$\%$ Total variance & 84.157 & 100.000 \\
Cumulative \% & 84.157 & \\
\hline
\end{tabular}

\section{Principal component analysis (PCA)}

The principal components analysis (PCA) are the uncorrelated variables, obtained by multiplying the original correlated variables with the eigenvalues. Surface water samples exhibited $100 \%$ in total sample variance (Table 7). Total variance of the PCs was $84.157 \%$ and $15.843 \%$ for PC 1 and PC 2, respectively. PC 1 is strongly correlated with $\mathrm{Pb}, \mathrm{Cd}, \mathrm{Cr}, \mathrm{Cu}, \mathrm{Al}, \mathrm{Ni}, \mathrm{Co}, \mathrm{Zn}$ and $\mathrm{Mn}$ and $\mathrm{PC} 2$ with $\mathrm{Hg}$. The sources of PC 1 and PC 2 were derived from both lithogenic and anthropogenic inputs of paint and textile industries. Two PCs were extracted in sediment. The total variance of the PCs was $80.325 \%$ and $19.675 \%$ for PC 1 and PC 2, respectively (Table 8). PC 1 is strongly correlated with $\mathrm{Pb}, \mathrm{Al}, \mathrm{Ni}, \mathrm{Co}, \mathrm{Mn}$ and \% sand and $\mathrm{PC} 2$ with 
Table 8 Component matrix of two-factor model with strong to moderate loadings in sediment

\begin{tabular}{lcc}
\hline & \multicolumn{2}{c}{ Component } \\
\cline { 2 - 3 } Eigenvalues (0.6) & PC 1 & PC 2 \\
\hline $\mathrm{Pb}$ & 0.998 & 0.059 \\
$\mathrm{Cd}$ & 0.793 & -0.609 \\
$\mathrm{Cr}$ & -0.977 & 0.212 \\
$\mathrm{Cu}$ & -0.894 & 0.448 \\
$\mathrm{Hg}$ & 0.609 & 0.793 \\
$\mathrm{Al}$ & 0.962 & 0.274 \\
$\mathrm{Ni}$ & 0.948 & 0.317 \\
$\mathrm{Co}$ & 0.998 & 0.070 \\
$\mathrm{Zn}$ & -0.986 & 0.169 \\
$\mathrm{Mn}$ & 0.998 & 0.059 \\
\%Silt & -0.892 & -0.452 \\
\%Sand & 0.909 & 0.416 \\
\%Clay & -0.978 & -0.210 \\
\%OC & -0.580 & 0.815 \\
\%OM & -0.772 & 0.635 \\
Eigenvalue & 12.049 & 2.95 \\
\%Total variance & 80.325 & 19.675 \\
Cumulative \% & 80.325 & 100.00 \\
\hline
\end{tabular}

$\mathrm{Hg}$ and \% OC. This is due to the sources of industrial and agricultural effluents.

\section{Cluster analysis (CA)}

CA was executed using square root and Bray-Curtis similarity to show the similarity among the parameters that contribute hugely to water pollution. From the output of the cluster analysis total, three clusters were found during different seasons. Cluster 1 includes $\mathrm{Al}$ and $\mathrm{Mn}$; cluster 2: $\mathrm{Co}, \mathrm{Cr}$ and $\mathrm{Zn}$; and cluster $3: \mathrm{Ni}, \mathrm{Pb}$ and $\mathrm{Cu}$ (Fig. 4). $\mathrm{Al}$ and $\mathrm{Mn}$ represent strong linkage with minimum cluster distance that indicates those parameters have influencing power during seasonal variations. Parameters that are assembled together in less distance have a higher attraction with similar identical behaviour during temporal variations and also exert a possible effect on each other. Furthermore, $\mathrm{Co}, \mathrm{Cr}$ and $\mathrm{Zn}$ have also strong linkage but lesser than cluster 1 but contribute largely to the environment. $\mathrm{Ni}, \mathrm{Pb}$ and $\mathrm{Cu}$ are under the group of cluster 3 with minimum distance than cluster 1 and cluster 2 but have effects on the environment. This is revealed that these are affected by untreated industrial effluents from paint and textile and also agricultural inputs and domestic wastes (Chung et al. 2016). In the case of sediment, cluster 1 includes $\mathrm{Cd}$ and $\mathrm{Hg}$; cluster 2: \% $\mathrm{OC}$ and \%OM; cluster 3: $\mathrm{Co}, \mathrm{Pb}, \mathrm{Cr}, \mathrm{Cu}, \mathrm{Ni}$ and \%clay; and cluster 4: \%silt, $\mathrm{Mn}$, $\mathrm{Zn}$ and \%sand (Fig. 5). Cd and $\mathrm{Hg}$ denote strong linkage with minimum cluster distance that designates those metals to have influencing power during seasonal variations. Heavy metals that are assembled together in less distance have a higher attraction with similar identical behaviour during temporal variations and have a possible effect on each other. \%OC and \%OM formed cluster 2 with minimum cluster distance. Moreover, $\mathrm{Co}, \mathrm{Pb}, \mathrm{Cr}, \mathrm{Cu}, \mathrm{Ni}$ and \%clay have also strong linkage but lesser than cluster 1 and cluster 2 but contribute largely in the environment. $\%$ Silt, $\mathrm{Mn}, \mathrm{Zn}$ and \%sand are under the group of cluster 4 with minimum distance than clusters 1,2 and 3 but have effects on the environment. This reflected the influence of effluents discharged from industries.
Fig. 3 Graph showing mean concentrations $(\mathrm{mg} / \mathrm{kg})$ of heavy metals in sediment during three seasons

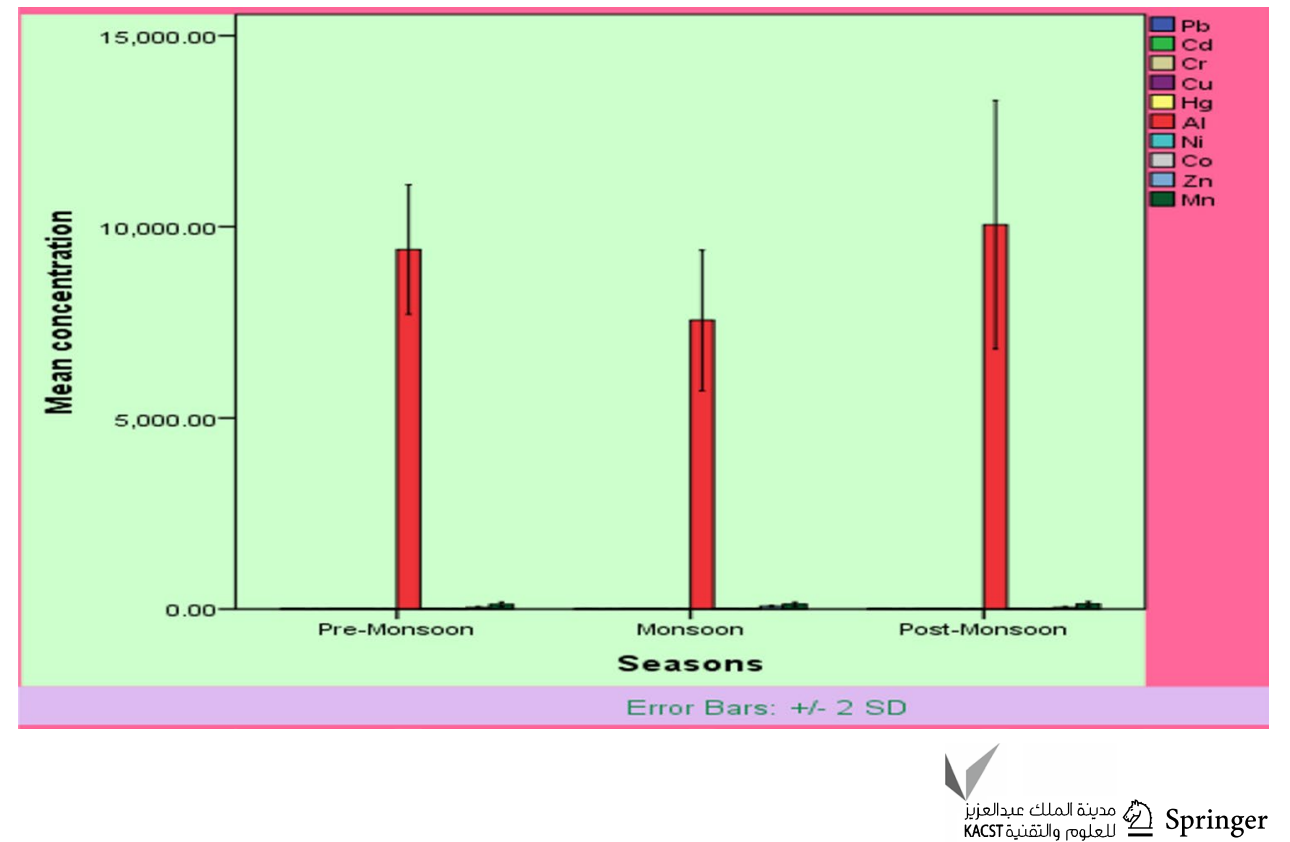


Cluster Analysis

Group average

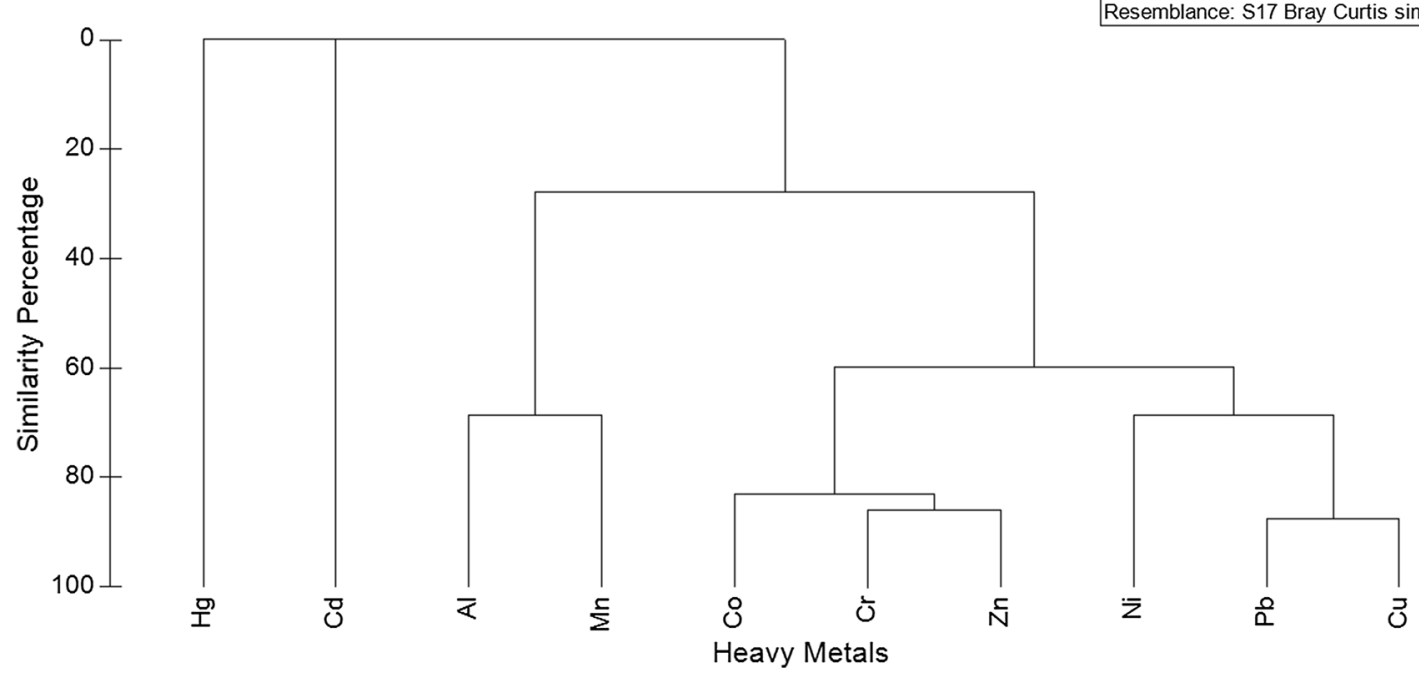

Fig. 4 Dendrogram showing the percentage of similarity among heavy metals during different seasons

Fig. 5 Dendrogram showing the percentage of similarity among heavy metals and soil quality variables in sediment during different seasons $[\mathrm{OC}=$ organic carbon; $\mathrm{OM}=$ organic matter]

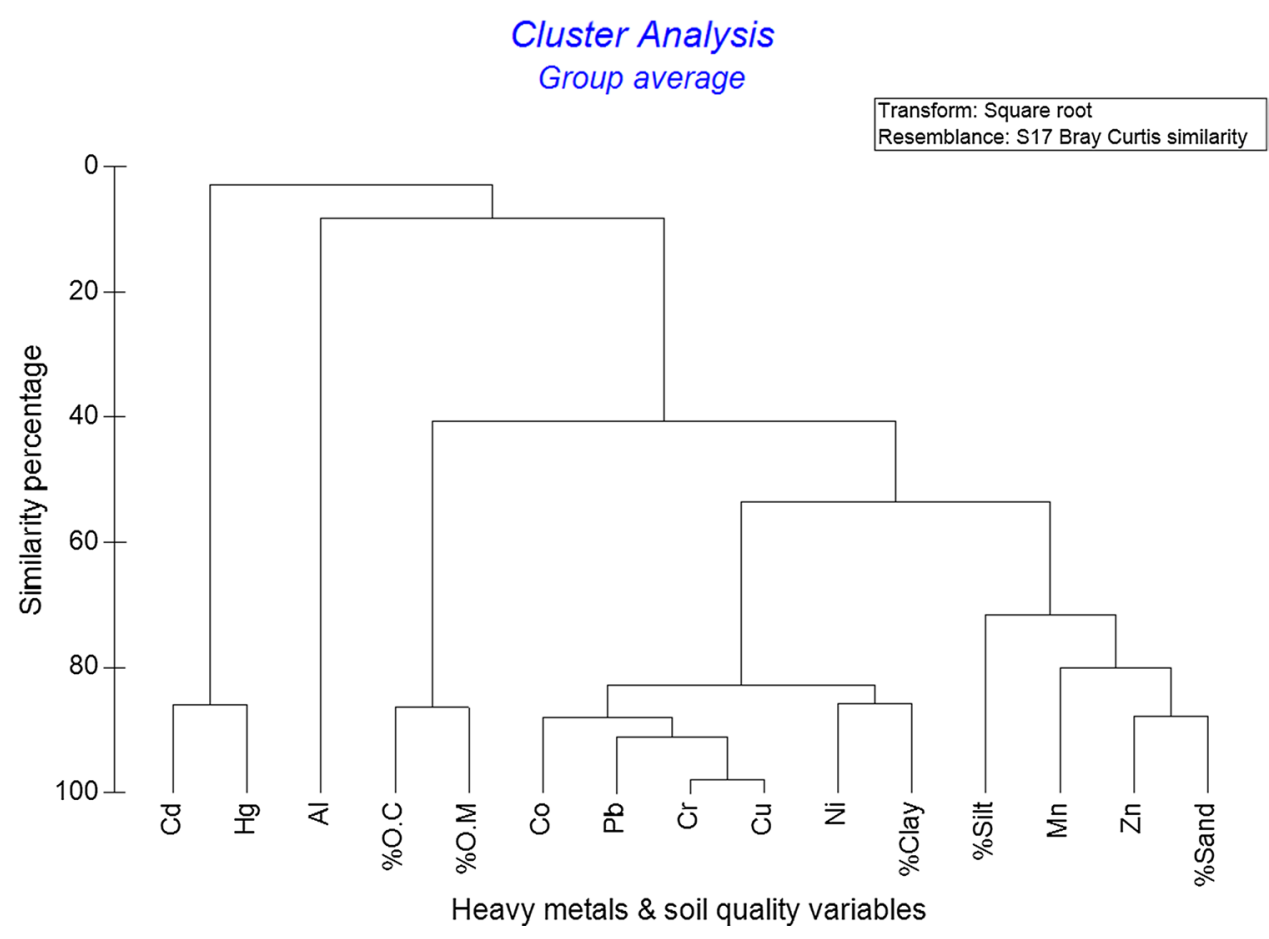

\section{Conclusions}

Classical multivariate statistical analysis was used to evaluate the contamination sources of heavy metals at the Old Brahmaputra River. The observed order of heavy metal concentrations in surface water and sediments is as follows: $\mathrm{Al}>\mathrm{Mn}>\mathrm{Ni}>\mathrm{Co}>\mathrm{Cu}>\mathrm{Pb}>\mathrm{Zn}>\mathrm{Cr}>\mathrm{Cd}>\mathrm{Hg}$ in $\mathrm{mg} / \mathrm{l}$ and $\mathrm{Al}>\mathrm{Mn}>\mathrm{Zn}>\mathrm{Ni}>\mathrm{Pb}>\mathrm{Cr}>\mathrm{Cu}>\mathrm{Co}>\mathrm{C}$ $\mathrm{d}>\mathrm{Hg}$ in $\mathrm{mg} / \mathrm{kg}$, respectively. It suggested that effluents were discharged from paint and textile industries, irrigation and domestic wastes and also minor input from geogenic sources. Most of the metals exceeded the permissible limit set by the standards. PCA suggested that the contribution of metals in water and sediments was derived from the anthropogenic origin in addition to lithogenic 
sources. Moreover, grain size (size of sand, silt, clay) and organic matter acted as efficient scavengers for metals in sediments. Cluster analysis indicated that anthropogenic impact was accountable for monitoring the variability of metals in water and sediments and these metals leached from industrial wastewater. This research showed that the classical statistical analysis was a significant tool to identify contamination sources and origins. Further studies are needed on metal speciation and effects on metal uptake by human and organisms.

Acknowledgements The authors are grateful to the Bangladesh Council of Scientific and Industrial Research (BCSIR), Chittagong. The proposed research is a major contribution of Biodiversity, Environment and Climate Change Research Laboratory, Faculty of Marine Sciences and Fisheries, University of Chittagong.

\section{Compliance with ethical standards}

Conflict of interest The authors declare that there is no conflict of interest.

Open Access This article is distributed under the terms of the Creative Commons Attribution 4.0 International License (http://creativeco mmons.org/licenses/by/4.0/), which permits unrestricted use, distribution, and reproduction in any medium, provided you give appropriate credit to the original author(s) and the source, provide a link to the Creative Commons license, and indicate if changes were made.

\section{References}

Agency for Toxic Substances and Disease Registry (ATSDR) (2004) Agency for toxic substances and disease registry, Division of Toxicology, Clifton Road, NE, Atlanta, GA. http://www.atsdr .cdc.gov/toxprofiles/

Ahmad MK, Islam S, Rahman S, Haque MR, Islam MM (2010) Heavy metals in water, sediment and some fishes of Buriganga River, Bangladesh. Int J Environ Res 4:321-332

Ahmed MK, Ahamed S, Rahman S, Haque MR, Islam MM (2009) Heavy metals concentration in water, sediments and their bioaccumulation in some freshwater fishes and mussel in Dhaleshwari River, Bangladesh. Terr Aquat Environ Toxicol 3:33-41

Ahmed ATB, Mandal S, Chowdhury DA, Rayhan MA, Tareq Rahman M (2012) Bioaccumulation of some heavy metals in Ayre fish (Sperata aor Hamilton, 1822), Sediment and water of Dhaleshwari River in dry season, Bangladesh. J Zool 40:147-153

Ahmed MK, Baki MA, Islam MS, Kundu GK, Sarkar SK, Hossain MM (2015a) Human health risk assessment of heavy metals in tropical fish and shell fish collected from the river Buriganga, Bangladesh. Environ Sci Pollut Res 22:15880-15890

Ahmed MK, Shaheen N, Islam MS, Al-Mamun MH, Islam S, Banu CP (2015b) Trace elements in two staple cereals (rice and wheat) and associated health risk implications in Bangladesh. Environ Monit Assess 187:326-336

Ahmed MK, Shaheen N, Islam MS, Al-Mamun MH, Islam S, Mohiduzzaman M, Bhattacharjee L (2015c) Dietary intake of trace elements from highly consumed cultured fish (Labeo rohita, Pangasius pangasius and Oreochromis mossambicus) and human health risk implications in Bangladesh. Chemosphere 128:284-292

Alhashemi AH, Sekhavatjou MS, Kiabi BH (2012) Bioaccumulation of trace elements in water, sediment, and six fish species from a freshwater wetland, Iran. Microchem J 104:1-6

Amacher GS, Brazee RJ, Bulkley JW, Moll RA (1989) Application of wetland valuation techniques; examples from great lakes coastal wetlands. School of Natural Resources, The University of Michigan and Institute of Water Research, Michigan State University, East Lansing

APHA (American Public Health Association) (1995) Standard methods for the examination of water and waste water, 19th edn. APHA (American Public Health Association), Washington DC

Bai J, Xiao R, Cui B, Zhang K, Wang Q, Liu X, Gao H, Huang L (2011) Assessment of heavy metal pollution in wetland soils from the young and old reclaimed regions in the Pearl River Estuary, South China. Environ Pollut 159:817-824

Balkis N, Aksu A, Okus E, Apak R (2010) Heavy metal concentrations in water, suspended matter, and sediment from Gokova Bay, Turkey. Environ Monit Assess 167:359-370

Banu Z, Chowdhury MSA, Hossain MD, Nakagami K (2013) Contamination and ecological risk assessment of heavy metal in the sediment of Turag River, Bangladesh: an index analysis approach. J Water Resour Prot 5:239-248

Bhuiyan MAH, Dampare SB, Islam MA, Suzuki S (2015) Source apportionment and pollution evaluation of heavy metals in water and sediments of Buriganga River, Bangladesh, using multivariate analysis and pollution evaluation indices. Environ Monit Assess 187:4075

Bhuyan MS, Islam MS (2017) A critical review of heavy metal pollution and its effects in Bangladesh. Environ Energy Econ 2:12-25

Bhuyan MS, Bakar MA, Islam MS, Akhtar A (2016) Heavy metals status in some commercially important fishes of Meghna river adjacent to Narsingdi District, Bangladesh: health risk assessment. Am J Life Sci 4:60-70

Camusso M, Vigano L, Baitstrini R (1995) Bioaccumulation of trace metals in rainbow trout. Ecotoxicol Environ Saf 31:133-141

Censi P, Spoto SE, Saiano F, Sprovieri M, Mazzola S (2006) Heavy metals in Coastal water system. A case study from North Western Gulf of Thailand. Chemosphere 64:1167-1176

Chung SY, Venkatramanan S, Park N, Ramkumar T, Sujitha SB, Jonathan MP (2016) Evaluation of physicochemical parameters in water and total heavy metals in sediments at Nakdong River Basin, Korea. Environ Earth Sci 75:50

Chung SY, Venkatramanan S, Park KH, Son JH, Selvam S (2018) Source and remediation for heavy metals of soils at an iron mine of Ulsan City, Korea. Arab J Geosci 11:769

Datta DK, Subramanian V (1998) Distribution and fractionation of heavy metals in the surface sediments of the Ganges-Brahmaputra-Meghna river system in the Bengal basin. Environ Geol 36:93-101

ECR (Environmental Conservation Rules) (1997) Bangla text of the rule was published in the Bangladesh gazette, extra-ordinary issue of 28-8-1997 and amended by notification SRD29 low/2000 of 16 Feb 2002

EPA (1986) Office of water policy and technical guidance on interpretation and implementation of aquatic life metals criteria. EPA, Washington DC

EPA (Environmental Protection Agency) (2002) Risk assessment: technical background information. RBG table. https://www. epa.gov/risk/risk-assessment-guidelines. Accessed 23 Mar 2009

Ergul HA, Topcuoglu S, Olmez E, Kırbaşoglu C (2008) Heavy metals in sinking particles and bottom sediments from the eastern Turkish coast of the Black Sea. Estuar Coast Shelf Sci 78:396-402 
Faisal I, Shammin R, Junaid J (2004) Industrial pollution in Bangladesh. World Bank, Washington DC

FAO (1985) Compilation of legal limits for hazardous substances in fish and fishery products. Food and Agriculture Organisation. Fishery circular no. 466:5-10

Fernandes C, Fontaínhas-Fernandes A, Cabral D, Salgado MA (2008) Heavy metals in water, sediment and tissues of Liza saliens from Esmoriz-Paramos lagoon, Portugal. Environ Monit Assess $136: 267-275$

Forstner U (1983) Metal concentration in river lake and ocean waters. In: Forstner U, Whitman GT (eds) Metal pollution in the aquatic environments. Springer, New York, pp 77-109

Gao X, Chen CTA, Wang G, Xue Q, Tang C, Chen S (2009) Environmental status of day a bay surface sediments inferred from a sequential extraction technique. Estuar Coast Shelf Sci 86:369-378

Grigoratos T, Samara C, Voutsa D, Manoli E, Kouras A (2014) Chemical composition and mass closure of ambient coarse particles at traffic and urban background sites in Thessaloniki, Greece. Environ Sci Pollut Res 21:7708-7722

Hassan M, Mirza ATM, Rahman T, Saha B, Kamal AKI (2015) Status of heavy metals in water and sediment of the Meghna River, Bangladesh. Am J Environ Sci 11:427-439

Islam F, Rahman M, Khan SSA, Ahmed B, Bakar A, Halder M (2013) Heavy metals in water, sediment and some fishes of Karnofuly River, Bangladesh. Pollut Res 32:715-721

Islam MM, Rahman SL, Ahmed SU, Haque MKI (2014) Biochemical characteristics and accumulation of heavy metals in fishes, water and sediments of the river Buriganga and Shitalakhya of Bangladesh. J Asian Sci Res 4:270-279

Islam MS, Ahmed MK, Habibullah-Al-Mamun M, Hoque MF (2015a) Preliminary assessment of heavy metal contamination in surface sediments from a river in Bangladesh. Environ Earth Sci 73:1837-1848

Islam MS, Ahmed MK, Raknuzzaman M, Habibullah-Al-Mamun M, Masunaga S (2015b) Metal speciation in sediment and their bioaccumulation in fish species of three urban rivers in Bangladesh. Arch Environ Contam Toxicol 68:92-106

Islam MS, Ahmed MK, Raknuzzaman M, Habibullah-Al-Mamun M, Masunaga S (2015c) Assessment of trace metals in fish species of urban rivers in Bangladesh and health implications. Environ Toxicol Pharmacol 39:347-357

Islam MS, Ahmed MK, Raknuzzaman M, Habibullah-Al-Mamun M, Islam MK (2015d) Heavy metal pollution in surface water and sediment: a preliminary assessment of an urban river in a developing country. Ecol Ind 48:282-291

Islam SMD, Bhuiyan MAH, Rume T, Mohinuzzaman M (2016a) Assessing heavy metal contamination in the bottom sediments of Shitalakhya River, Bangladesh; using pollution evaluation indices and geo-spatial analysis. Pollution 2:299-312

Islam MS, Bhuyan MS, Monwar MM, Akhtar A (2016b) Some health hazard metals in commercially important coastal Molluscan species in Bangladesh. Bangladesh J Zool 44:123-131

Jordao CP, Pereira MG, Bellato CR, Pereira JL, Matos AT (2002) Assessment of water systems for contaminants from domestic and industrial sewages. Environ Monit Assess 79:75-100

Khan S, Cao Q, Zheng YM, Huang YZ, Zhu YG (2008) Health risks of heavy metals in contaminated soils and food crops irrigated with wastewater in Beijing, China. Environ Pollut 152:686-692

Kibria G, Hossain MM, Mallick D, Lau TC, Wu R (2016a) Monitoring of metal pollution waterways across Bangladesh and ecological and public health implications of pollution. Chemosphere 165:1-9

Kibria G, Hossain MM, Mallick D, Lau TC, Wu R (2016b) Trace/heavy metal pollution monitoring in estuary and coastal area of the Bay of Bengal, Bangladesh and implicated impacts. Mar Pollut Bull 105:93-402
Martin JAR, Arana CD, Ramos-Miras JJ, Gil C, Boluda R (2015) Impact of 70 years urban growth associated with heavy metal pollution. Environ Pollut 196:156-163

Mohiuddin KM, Alam MM, Ahmed I, Chowdhury AK (2015) Heavy metal pollution load in sediment samples of the Buriganga river in Bangladesh. J Bangladesh Agric Univ 13:229-238

Mokaddes MAA, Nahar BS, Baten MA (2013) Status of heavy metal contaminations of river water of Dhaka Metropolitan City. J Environ Sci Nat Resour 5:349-353

Morillo J, Usero J, Gracia I (2004) Heavy metal distribution in marine sediments from the southwest coast of Spain. Chemosphere 55:431-442

Nduka JK, Orisakwe OE (2011) Water-quality issues in the Niger Delta of Nigeria: a look at heavy metal levels and some physicochemical properties. Environ Sci Pollut Res 18:237-246

Nicolau R, Galera CA, Lucas Y (2006) Transfer of nutrients and labile metals from the continent to the sea by a small Mediterranean river. Chemosphere 63:469-476

NNPC, RIP (1986) Reports for the establishment of controls and standards against petroleum related pollution in Nigeria, no RPI/R/84/15-7p111A 100-103

Nouri J, Lorestani B, Yousefi N, Khorasani N, Hasani AH, Seif S, Cheraghi M (2011) Phytoremediation potential of native plants grown in the vicinity of Ahangaran lead-zinc mine (Hamedan, Iran). Environ Earth Sci 62:639-644

Ozmen H, Kulahçi F, Çukurovali A, Dogru M (2004) Concentrations of heavy metal and radioactivity in surface water and sediment of Hazar Lake (Elazı $\breve{g}$, Turkey). Chemosphere 55:401-408

Pan K, Wang WX (2012) Trace metal contamination in estuarine and coastal environments in China. Sci Total Environ 422:3-16

Rahman MM, Asaduzzaman M, Naidu R (2013) Consumption of arsenic and other elements from vegetables and drinking water from an arsenic-contaminated area of Bangladesh. J Hazard Mater 262:1056-1063

Rahman MS, Saha N, Molla AH (2014) Potential ecological risk assessment of heavy metal contamination in sediment and water body around Dhaka export processing zone, Bangladesh. Environ Earth Sci 71:2293-2308

Rashid H, Hasan MN, Tanu MB, Parveen R, Sukhan ZP, Rahman MS, Mahmud Y (2012) Heavy metal pollution and chemical profile of Khiru River, Bangladesh. Int J Environ 2:57-63

Saha P, Hossain M (2011) Assessment of heavy metal concentration and sediment quality in the Buriganga River, Bangladesh. In: International proceedings of chemical, biological and environmental engineering, Singapore City, 26-28 February 2010, pp. VI-384-VI-387

Sanchez-Chardi A, Lopez-Fuster MJ, Nadal J (2007) Bioaccumulation of lead, mercury, and cadmium in the greater white-toothed shrew, Crocidura russula, from the Ebro Delta (NE Spain): sexand age-dependent variation. Environ Pollut 145:7-14

Sharma RK, Agrawal M, Marshall FM (2007) Heavy metals contamination of soil and vegetables in suburban areas of Varanasi, India. Ecotoxicol Environ Saf 66:258

Sun TH, Zhou QX, Li PJ (2001) Pollution ecology. Science Press, Beijing, pp 160-194

Tarra-Wahlberg NH, Flachierm A, Lane SN, Sangfors O (2001) Environmental impacts and metal exposure of aquatic ecosystems in rivers contaminated by small scale gold mining: the Puyango River Basin, Sourthen Ecuador. Sci Total Environ 278:239-261

Thompson M, Howarth RJ (1976) Duplicate analysis in geochemical practice. Analyst 101:690-698

USEPA (1999) US environmental protection agency: screening level ecological risk assessment protocol for hazardous waste combustion facilities. Appendix E: toxicity reference values. USEPA, Washington DC, p 3 
USEPA (2006) Drinking water standards and health advisories. Office of water, Environmental Protection Agency, Washington DC

Venkatramanan S, Chung SY, Ramkumar T, Selvam S (2015a) Environmental monitoring and assessment of heavy metals in surface sediments at Coleroon River Estuary in Tamil Nadu, India. Environ Monit Assess 187:505

Venkatramanan S, Chung SY, Ramkumar T, Gnanachandrasamy G, Kim TH (2015b) Evaluation of geochemical behavior and heavy metal distribution of sediments: the case study of the Tirumalairajan river estuary, southeast coast of India. Int J Sedim Res 30:28-38

Venugopal T, Giridharan L, Jayaprakash M (2009) Characterization and risk assessment studies of bed sediments of river Adyar, an application of speciation study. Int J Environ Res 3:581-598

Wang YB, Liu CW, Liao PY, Lee JJ (2014) Spatial pattern assessment of river water quality: implications of reducing the number of monitoring stations and chemical parameters. Environ Monit Assess 186:1781-1792

WHO (2004) Guidelines for drinking water quality, 3rd edn. World Health Organization, Geneva, p 515

WHO (2008) Guidelines for drinking water quality, Second addendum to third edition. WHO, Geneva
Wilson B, Pyatt FB (2007) Heavy metal dispersion persistence, and bioaccumulation around an ancient copper mine situated in Anglesey, UK. Ecotoxicol Environ Saf 66:224-231

Yi Y, Yang Z, Zhang S (2011) Ecological risk assessment of heavy metals in sediment and human health risk assessment of heavy metals in fishes in the middle and lower reaches of the Yangtze river basin. Environ Pollut 159:2575-2585

Zakir HM, Moshfiqur RM, Rahman A, Ahmed I, Hossain MA (2012) Heavy metals and major ionic pollution assessment in waters of midstream of the river Karatoa in Bangladesh. J Environ Sci Nat Resour 5:149-160

Zhang C, Qiao Q, Piper JDA, Huang B (2011) Assessment of heavy metal pollution from a Fe-smelting plant in urban river sediments using environmental magnetic and geochemical methods. Environ Pollut 159:3057-3070

Zhou QX, Kong FX, Zhu L (2004) Ecotoxicology: principles and methods. Science Press, Beijing, pp 161-217

Publisher's Note Springer Nature remains neutral with regard to jurisdictional claims in published maps and institutional affiliations. 